\title{
A Measurement Tool for Repeated Measurement of Assessment of University Students' Writing Skill: Development and Evaluation *
}

\author{
Ayfer SAYIN **
}

Nilüfer KAHRAMAN ***

\begin{abstract}
This study summarizes the development and the application of a four-week repeated assessment scale that was designed to measure the advanced writing skills of college students. The storyline was written by the first author and required respondents to write one or more sentences to the given developing storyline of the week. Each week's narrative was written to tell a part of a story that integrates into a single storyline over the weeks. For the application, each week, the respondents from a volunteered sample of 74 were asked 1) to write to a continuation to the developing storyline of the week (the instruction stated that this was the first or the second or the third or the last part of the storyline) and 2) to rate their overall mood that week (1 to 5,5 indicating a great mood). Writings of the students (responses) were then coded by multiple raters with respect to three subskill components; namely expression, aesthetics, and creativity. The hypothesized tie between the fluctuations observed in the sense of well-being and the writing performance of the students over the weeks and whether and to what extent the creativity subcomponent was more subject to the influence of student's mood changes when compared to the clarity of expression or the aesthetics subskill. However, the results show that when the changes in writing performances of the whole group were examined instead of that of individuals over time, there were no significant differences to be found. It is recommended that it might be more useful than the classical one-shot assessment design.
\end{abstract}

Key Words: Longitudinal study, longitudinal measurement tool, expression skill, perception of aesthetics, creativity skill.

\section{INTRODUCTION}

With the aim of educational reforms for a high quality, future-oriented education responding to the needs of the society, the 2006 European Parliament and Council published their recommendations on the Key Competencies for Lifelong Learning. The eight key competencies that students are recommended to be equipped with are listed as follows: communicating in the mother tongue, communicating in a foreign language, mathematical, scientific and technological competence, digital competence, learning to learn, social and civic competence, sense of initiative and entrepreneurship, and cultural expression and awareness. In this report, it is stated that each competency is indeed highly associated with each other, and all the competencies intersect with critical thinking, problem solving, creative thinking, and establishing empathy (European Commission-EC, 2006). Similarly, the first of competence of Turkey Qualifications Framework is given as:

Concepts, thoughts, ideas, emotions, and phenomena to express both orally and in writing and interpretation (listening, speaking, reading and writing); to interact in an appropriate and creative way linguistically in all social and cultural contexts such as

\footnotetext{
* This study was presented at the 6th International Congress on Measurement and Evaluation in Education and Psychology held in Kosovo on September 05-08, 2018.

** Assoc. Prof., Gazi University, Faculty of Gazi Education, Ankara-Turkey, ayfersayin@ gazi.edu.tr, ORCID ID: 00000003-1357-5674

*** Prof., Gazi University, Faculty of Gazi Education, Ankara-Turkey, nkahraman@gazi.edu.tr, ORCID ID: 0000-00032523-0155
}

To cite this article:

Sayın, A., \& Kahraman, N. (2020). A measurement tool for repeated measurement of assessment of university students' writing skill: Development and evaluation. Journal of Measurement and Evaluation in Education and Psychology, 11(2), 113-130. doi: 10.21031/epod.639148 
education and training, workplace, home and entertainment (Mesleki Yeterlik KurumuMYK, 2016, p.23).

It is seen that the focus is on the skill development of individuals in student competencies defined both in the international and national fields. However, it requires a process both for a person to have knowledge or skills and to determine the knowledge and skills he or she has. Furthermore, possessing knowledge or skill does not necessarily mean that an individual can express or display that knowledge or skill. To illustrate, an individual

- may not be aware of the knowledge or skill s/he possesses,

- may not consider this knowledge essential,

- may not know how to convey this knowledge to other people (Karadüz, 2010).

Although a person may possess a skill to a certain degree, such as critical thinking, problem solving, or creative thinking, it is possible that that individual's relative standing in a group or with herself/himself over time may not be captured properly due to the limitations brought about the assessment tools used.

In traditional testing settings used for the assessment of writing proficiency, students often are asked to write a composition given a subject or the main idea, such as friendship or about some assertion, such as looking and seeing are not the same. Here it can be argued that, completing the task in this manner, students might not be able to use their creativity to the full extent and perhaps might be less motivated, and hence, willing to try out strategies, routes, etc. that may help them expand their skills that they may not even know that they had. In other words, it can be argued that measurement tools to date developed for the assessment of writing skills are often limit their focus on the end product of the students' performance rather than the process experienced leading to the end product. Moreover, it is often the case that students are commonly given a passive role through which they cannot either manage or show how they managed their writing processes (Coşkun, 2013; Oral, 2014). Ülper (2008), for example, states that it is likely that the conventional means of assessments would miss essential components of writing competence in this manner, such as creativity. Hence, it would be important for writing assessments to focus on both what the students write and how they write as well as to explore about the best conditions that can provide students an opportunity to discover their own writing skills, and to manage their own writing processes (Brown, 2001). Within the scope of the argument above, this study aimed to develop a repeated assessment tool that can be used to measure college students' advanced writing skills.

\section{Longitudinal Tests as An Alternative Measurement Tool}

In this study, a process related to the development and evaluation of an alternative measurement tool, which can be used as a longitudinal measurement tool because it includes repeated measurements, has been introduced. Longitudinal studies are also called development studies, and they are carried out based on data collection on the same group with repetitive measurements in order to reveal the timedependent variables (Cohen, Manion, \& Morrison, 2005; Fraenkel \& Wallen, 2009). Especially in studies that examine students' achievements in class, longitudinal research needs to be highlighted (Butler \& Schnellert, 2012; Richardson \& Liang, 2008). Because measuring the writing skills of the students in a longitudinal way, not allowing them to measure more than one time, will provide more detailed and deeper and perhaps different results than one-time measurement. The feedback that can be provided with such information to be obtained will enable the individual to become aware of the knowledge and skills he/she has, to help him feel belonging to the process and to try various ways in the process of expression. Longitudinal measurements also provide rich information to the teacher and allow students to give effective feedback (Compton-Lilly, 2003). Therefore, longitudinal measurements in class research produce much more reliable and valid results than a single measurement (Carini, 2001; Comber \& Barnett, 2003; Ekwall \& Shanker, 1993; Lemke, 2005; Leslie \& Caldwell, 2006). In line with all this information, it is aimed to develop a measurement tool that allows longitudinal measurements within the scope of the research. 
One of the important skills that 21 st century individuals should acquire during the education process is creativity, and since creativity is not acquired in a single week or time period, it shows a longitudinal feature by nature like other skills. Language skills also come to the fore in expressing high-level skills such as creativity. Wittgenstein (2005) states that the conditions in which individuals live affect the process of understanding and understanding; expresses that the same words may differ in usage and context. Because the language and expressions used by individuals are a reflection of their lifestyle, and the language used by people takes shape according to lifestyle variables. In other words, it is necessary to consider the language in its natural environment and when people say something, take into account the situations they are in and the behaviors that accompany them (Wittgenstein, 2012). Accordingly, within the scope of the research, students' language skills were carried out with a focus on writing skills in which three sub-dimensions of expression, creativity and aesthetic skills were discussed.

The fact that the skills expected from individuals in the 21st century are more complex and variable in structure compared to the previous century, brings about the change of the methods used in measuring and evaluating these skills. Because creative writing does not fit into a fenced area or a pattern; It is the process of combining emotions and thoughts with imagination and transferring to the article in a subjective way (Horng, Hong \& Chanlin, 2005; Oral, 2014) and in order for this process to take place, students need tasks in which they can use their creativity and bring their feelings and thoughts together. Measurement of creativity or aesthetic success can produce biased results with tasks that are limited and clearly seen what individuals expect from them.

In this study, the story completion technique was used, but unlike the traditional story completion technique, the story was divided into four parts, similar to a mini-series consisting of four parts. Each piece is united in itself and prioritizes the psychological state of the hero. Each piece of the story can be observed by spreading the practices for four weeks and by following the adaptation of the students to the process, the way they want to be able to use their creativity and aesthetic features, in other words, as cognitive and affective skills. The ability of individuals to express their abilities about writing skills in line with their motivation, interest and desires, but nevertheless in the context of story pieces given weekly and in succession, and their changing or unchanging characteristics depending on their emotional state over time. a measuring tool that recognizes.

\section{The Aim of the Study}

The aim of the present study was to develop a longitudinal assessment tool for measuring the writing skills of college students over four consecutive weeks to be rated for their sub-skills: 1) clarity of expression, 2) creativity, and 3) aesthetics. In order to conduct reliability and validity studies, data were collected from 74 college students who volunteered to participate in the four-week administrations. A survey assessing students' weekly mood was also carried out along with these administrations. In the first week of the four, students were given the first chapter of a story and were asked to write a continuation of one to several sentences. During the following three weeks, the same direction was given for the following three chapters of the story. Each chapter in the story had integrity within itself and was about the psychological state of a protagonist. Each week, students marked how they felt that week on a scale of 1 to 5 (very good).

Assessment development process and student performance related research questions were:

1. What should be the components of a longitudinal writing assessment tool that can be used to measure and track college students' expression, aesthetics and creativity writing subskills?

- How to develop the process and the tasks included?

- How to develop the scoring rubric? 
2. What are the weekly state and over the week changes in individual writing performances of the students with respect to Expression, Aesthetics and Creativity subskill dimensions? How do students' week moods affect their writing performances?

For each subskill

- How do students perform each week?

- How do students' performance change over the weeks?

- How do students' performance relate to their weekly mood?

3. How to interpret individual versus group level analysis results for the changes observed in the writing subskills (expression, aesthetics and creativity)? How do students' week moods affect their writing performance as a group?

4. What is the relationship between writing skills and weekly modes in the context of expression versus aesthetics versus creativity? Do the findings support the theoretical developments in this field?

\section{The Significance of the Study}

For the purpose of making inferences about university students' advanced writing skills, a measurement tool containing a four-week repeated assessment design was developed. In addition to a weekly mood scale, a scoring rubric was developed specifically to evaluate expression, aesthetics, and creativity subskills in the students' weekly writings. With the design, it was possible to evaluate whether and to what degree students' subskill performances were related not only to their knowledge but also to their mood, interest, and adaptation level to the writing (assessment) process. The fact that no similar study was found in the related literature adds to the significance of the present study. It is for the illustrating of an alternative measurement method to the literature in its task duties, which is named as dynamic text in the research and for the completion of stories. This is one of the other feature that strengthens the significance of this study. Moreover, the present study contributes to the literature by introducing dynamic text based writing assessments and scoring rubrics that were most suited for the utilized repeated assessment design.

\section{Assumptions and Limitations}

Within the scope of the study, four different parts of a single story were sent to the students who were asked to complete the story. As explained in the section on the development of the task, expert opinions were received on whether or not the different parts of the story stimulated the students to the same degree and whether the parts conveyed information in the same manner; hence, it was assumed that the parts of the story stimulated the students to the same degree.

The students produced their on-line responses every week between Sunday and Tuesday. It was assumed that the students' responses reflected their weekly standings given the constructs measured.

\section{METHOD}

During the data collection stage of the study, processes compatible with the longitudinal research design were followed. Longitudinal examinations were done to reveal the time-related variations of the variables by making repeated measures and collecting data from the same group (Cohen et al., 2005; Karasar, 2008; Fraenkel \& Wallen, 2009; Büyüköztürk, Çakmak, Akgün, Karadeniz, \& Demirel, 2010); examining a single group having common attributes is done to reveal the general tendency of a group and the variations and tendencies of the same individuals over a certain period of time (Fraenkel \& Wallen, 2009; Büyüköztürk et al., 2010). 


\section{Participants}

The current study was conducted with 74 students at Gazi University, who volunteered to take part in the four-week implementation stage during the 2016-2017 academic year. Hence, the convenience sampling, which is one of the purposeful sampling methods, was used.

\section{Data Collection Instrument}

The data of the present study were collected using an on-line platform where college students could $\log$ in every week, Sunday to Thursday, to respond to the assessment module, where they were also asked to self-rate their overall mood each week.

The implementation week of the data collection tools are presented in Table 1. The students' responses to the open-ended questions were scored independently by 5 experts. The weekly moods of the students were self-ratings and ranged from 1 to 5 (very good).

Table 1. Data Collection Tools and Implementation

\begin{tabular}{llll}
\hline Week of measurement & Text- (The Story of Hours and Centuries) & Text based questions & Evaluation of the week \\
\hline Week 1 & Section I: If only he could say "Maybe" & Text completion & Weekly mood \\
\hline Week 2 & Section II: The darkness of light & Text completion & Weekly mood \\
\hline Week 3 & Section III: Accident & Text completion & Weekly mood \\
\hline Week 4 & Section IV: The woman's dimple & Text completion & Weekly mood \\
\hline
\end{tabular}

\section{Data Analysis}

Initially, a scoring rubric was developed for the rating of the responses (continuations written by the students given the storyline of the week). Student responses were at most several sentences. With the rubric developed, the responses were coded by five separate raters initially. The Krippendorff Alpha coefficients and the Pearson correlation coefficients and Intra-Group Correlation Coefficients were calculated in order to compute inter-rater agreement and to choose the best performing raters. After these calculations were made, the three raters with the highest reliability were chosen, and student scores were computed using the ratings of these raters were used in the analyses.

Initially, the variations in students' writing skills based on the sub-dimensions of expression, aesthetics, and creativity were examined. Next, graphs were made use of, and based on expert opinions, students displaying similar score patterns were categorized into subgroups. Graphs were also constructed to identify how the weekly moods reported by the students participating in the study varied in combination with the writing skills, and the student sub-groups were labeled. Discriminant analyses were conducted to determine the validity of the students' weekly mood categorizations based on the expression, creativity, and aesthetics scores. Prior to these analyses, the assumptions of missing values, normality, multiple associations, and homogeneity of variance were examined.

After the students' individual writing skills were examined, group-based descriptive statistics were calculated. Subsequently, variance analysis in the repeated measurements was run to identify whether or not students' sub-dimension scores showed significant variance across the weeks. The data set was tested for its compatibility with the analysis in accordance with the assumptions of normality and sphericity.

\section{RESULTS}

The developmental stages and the final version of the longitudinal measurement tool developed. And piloted during the present study are presented in Figure 1. The measurement and data collection design are presented in Figure 1. 


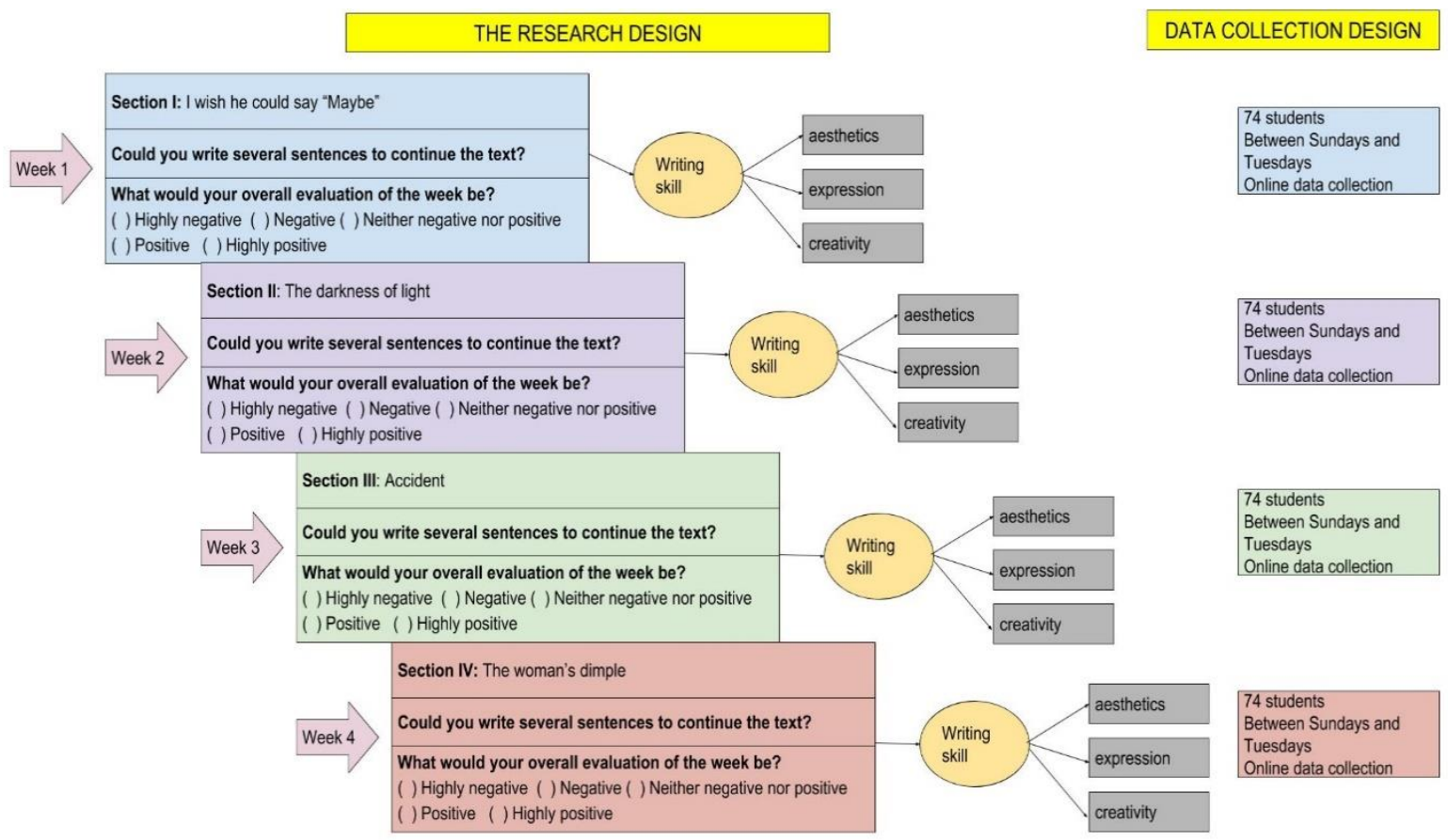

Figure 1. The Measurement and Data Collection Design

\section{What Should Be the Components of A Longitudinal Writing Assessment Tool That Can Be Used To Measure And Track College Students' Expression, Aesthetics And Creativity Writing Subskills?}

The students were sent a section of a story named as dynamic text each week and asked to complete the story texts with several sentences throughout the four weeks because meaning is a phenomenon that emerges over a course of time (Wittgenstein, 2014). The study aimed to make a longitudinal measurement of individuals' attribution of meaning to the story and what they found important within the context rather than measuring a situation in which condition of the individuals.

How to develop the process and the tasks included?

During the developmental process of the measurement tool, a dynamic story as a story possessing feature was created. Different from event stories, in which the introduction, development, and conclusion sections are clearly defined, situation stories are based on a central plot that is taken from one point and drawn towards a conclusion. In situation stories, the event sometimes portrays the beginning of the story, and sometimes it emerges towards the end of the story. What's important is not the event, but the effect of the protagonist upon the reader. In situation stories, also called modern stories, the understanding of time is also different as the chronological time flow is disrupted (Yakic1, Yücel, Doğan, \& Yelok, 2016). In situation stories, a pre-developed event is excluded from the story, and an analysis is made of the situation created by that event, and the events are not concluded so that the reader of the story can continue the story in his/her mind (Kolcu, 2013). Accordingly, there were two reasons why the situation story was preferred in the scope of the present study. First of all, since the research aimed to also measure such skills as creativity and aesthetics of students, which are related more to the cognitive domain, rather than having students follow up a story, the study aimed to reveal students' feelings, as well as their opinions. Secondly, as the story completion technique was used, the researchers wanted the readers to identify with the story so that they could easily complete the story.

Moreover, the story was constructed in accordance with the post-modernism movement using the technique of stream of consciousness. Accordingly, metaphors and allusions came to the fore in combining the sections forming the whole. As can be observed in Figure 1, there are seasonal transitions among the sections of the story. In addition, while the "woman's dimple" is described in 
the first three sections of the story as something beautiful, at the end of the story it disappears. With the consideration of the post-modern approach, the dimple in place of the "woman's eyes" disappears as the woman's eyes open. In the story, which was titled "Hours and Centuries" as it included the night and the events experienced, there is an allusion that the hours of a night stretch out like a century. After the story was finalized and divided into four sections, three expert opinions were received from experts on New Turkish Literature on the story text (with respect to expressions, descriptions, structure, and logical sequencing). After some of the expressions were modified, opinions of the first measurement and assessment expert (as regards the items) were received. Thus, the story component of the measurement tool, named as "dynamic text", was created.

The readers found the protagonist in his room at a time in the night and watched him go through all the details in his mind of a memory that didn't allow him to sleep. Suddenly the woman in his memories approached him on a spring day and the writer was introduced to the woman in his memories. A past moment experienced within the lives of the writer, and the woman is left incomplete. In the second section of the story, the protagonist is in the later hours of the night and is then looking outside the room. Within the lights he watches outside, he suddenly finds himself within a summer day memory. The reader, who had met the woman in the previous week, gets to know another attribute of the woman this time, and the talk between the two is again left incomplete. In other words, it is inscribed into the writer's soul or his thoughts. In the third section of the story, the night is slowly leaving its place to the dawning day, but the writer is still suffering under his thoughts. This time the reader witnesses where and how the writer meets the woman on an autumn day. But everything is left incomplete. In the last section of the story, the reader sees that it is morning, a winter morning. And as the night ends and the day dawns, everything that was experienced passes through his mind, and the situation that does not make him sleep starts to appear but is not known completely. The story created within the scope of the present study is presented in Table 2.

\section{How to develop the scoring rubric?}

Each week the responses given by the students to complete the storyline were examined to see in which category they could be evaluated. Thus, initially, the related literature was reviewed to identify the sub-dimensions of higher-order writing skills, and scorings were done by five raters. A holistic scoring key was created to score sub-categories. Then, modifications were done in the sub-dimensions in the rubric based on the raters' views and the inter-rater agreement analyses. Subsequently, the subdimensions of the writing skill, namely, aesthetics, expression, and creativity were identified. The scoring of each sub-dimension was done within the range of $0-4$, and the essential details were added. The modified version of the scoring rubric, which is scored with a holistic approach, was used by three raters (selected from the total 5 , due to higher reliability) to score the four-week responses of 74 students, and the rubric was finalized. The sub-dimensions in the rubric used for scoring are as follows:

- Creativity: If the students used cliché expressions, the response received 0 point; if they used creative and unique expressions, that is developed a new perspective, their response received a score between 1 to 4 points.

- Expression: The students' responses were scored between 0 to 4 points based on suitability to the flow (suitability to the context), meaningfulness, consistency, and coherence.

- Aesthetics: Students' descriptions in their expression in the texts, elevating the experiences, and catching a worthwhile tone were scored between 0 and 4 points.

Initially, the Pearson correlation coefficient was calculated based on the raters' scores, and the coefficients for the sub-dimensions for each week were found to range between .53 and .87. It was also determined that the correlation coefficient within the group calculated according to the answers of the raters was calculated between .53 and .88. Subsequently, the calculated Krippendorff Alpha coefficients for all the sub-dimensions and the weeks were found to range between .52 and .67 . 
Table 2. The Stories

\begin{tabular}{|c|c|}
\hline Week & Section \\
\hline 1 & $\begin{array}{l}\text { It's } 02.25 \ldots \text { As the room was imperceptibly dawning with the street lights, it was absorbing the entire quietness } \\
\text { of the night. It was not even allowing him to shut his foxy, mind-craving eyes. It was not possible anyway for } \\
\text { him to forget that day when the moist drops fell to the ground, and the weather was nice. How he had gotten } \\
\text { excited while getting dressed. He had gotten leave from work, gotten up early and ironed his shirt, and unsatisfied, } \\
\text { ironed it again. He had sat at a table in a tea garden, placed the flowers he brought with him on the table and then } \\
\text { waited for quite some time. Yes, there she was, coming... There was no wind blowing in the air, no moving leaf; } \\
\text { the universe was merely at a still. The woman with a dimple emerging on her cheek when she smiled sat across } \\
\text { him. Gazing at her, he attempted to say, "There are things I need to explain to you..." but the woman got the } \\
\text { jump on him; he couldn't say it. If only he could say "Maybe"... }\end{array}$ \\
\hline 2 & $\begin{array}{l}\text { It's } 03.27 \ldots \text { The room is quieter than the night... The lights of a flat from the opposite apartment building went } \\
\text { on. Perhaps there were others, apart from himself, that could not sleep. Or they got up just to drink water, who } \\
\text { knows? He wanted them to go to bed immediately and turn off the lights; the street lights were also to be turned } \\
\text { off. The entire world was to be buried in the darkness like the life he was living. Why were people making such } \\
\text { an effort to see the daylight anyway? He wished he could forget that summer daylight that caused his mind to } \\
\text { bleed. What would happen if people did not see people rushing here and there, the fighting children while playing } \\
\text { in the street, the men frustrated with the hot weather? They were in a hospital where there was a fan circulating } \\
\text { on the ceiling. The woman said, "I want to see you" and again smiled with a dimple appearing on her cheek. } \\
\text { What had the Little Prince said? "It is only in the heart that one can see rightly, what is essential is invisible to } \\
\text { the eye. Oh, how he could explain this to her, but he couldn't. If only he could say "Maybe"... }\end{array}$ \\
\hline 3 & $\begin{array}{l}\text { It's } 06.23 \ldots \text { He became happy when the room slowly started to enlighten because it was impossible for him to } \\
\text { justify himself during the nights when people knew his secrets. Everything slowed down during the nights; time } \\
\text { was becoming impatient to confront the things that were experienced. He wished he could stop the time on that } \\
\text { autumn day. The weather was warm, the leaves were yellow, people were happy... It was as if everyone were in } \\
\text { their corner preparing for a stormy winter. If he could slow down too; why was he proceeding so fast anyway? } \\
\text { He had just bought his car and was trying it out. It was too late when he had seen the woman crossing the street. } \\
\text { The intermingling sounds of the brakes, his heart, and the woman suddenly came to an end. How could he forget } \\
\text { the expression on the woman's frightened, angry, surprised, suffering eyes? The eyes of the woman instantly } \\
\text { closed, the pieces of broken glass shed blood, and her eyes never opened again. He sincerely wanted to say "I'm } \\
\text { sorry" but he couldn't because such an apology was not to be expressed with three words ... }\end{array}$ \\
\hline 4 & $\begin{array}{l}\text { It's } 08.11 \ldots \text { Was the room cold or was his life never going to warm up again? It was morning again today. He } \\
\text { had strolled in the room all night and watched the falling snow at times. Why hadn't the whiteness covering the } \\
\text { entire earth cover all the misdeeds? Why would people envisage the days that they know they would never } \\
\text { experience again? The accident he had on an autumn day, the police, prosecutor, complaints, petitions, prison, } \\
\text { and the most important of all the woman's eyes... He found the woman after his release from the prison; the } \\
\text { woman's eyes were closed; she had not wanted to be operated. He met her; became friends with her; he first } \\
\text { thought he would convince her. But later, he did not have the courage to build eye-contact with her. The woman } \\
\text { was like someone who had never lived or was impossible to live on earth. She was not beautiful; her hair was not } \\
\text { waving into the wind; and she did not like to talk much. But when she smiled unconsciously, such a dimple } \\
\text { appeared on her cheek that one could stay awake for days just to see it. } \\
\text { One spring day, he wanted to explain everything. But the woman got the jump. "I forgave the person who did } \\
\text { this to me," she said and added, "For me, there was no beauty in the world worth seeing until I met you..." One } \\
\text { spring day, the woman had surgery, and her eyes opened. Again they came eye to eye. The woman smiled, but } \\
\text { this time no dimple accompanying her smile appeared on her cheek... }\end{array}$ \\
\hline
\end{tabular}

\section{What Are the Weekly State And Over the Week Changes In Individual Writing Performances Of The Students With Respect To Narration, Aesthetics And Creativity Subskill Dimensions? How Do Students' Week Moods Affect Their Writing Performances?}

During the evaluation process of the measurement tool, initially individual variations (across the weeks for the same individual) and then group-based variations (each week for all the individuals in the group) in students' writing skill levels based on the repeated measurements of the sub-dimensions of expression, aesthetics, and creativity were examined. 
Sayın, A., Kahraman, N. / A Measurement Tool for Repeated Measurement of Assessment of University Students' Writing Skill: Development and Evaluation

How do students perform each week?

Table 3. The Weekly Variations in Students' Scores

\begin{tabular}{llrrrrrr}
\hline Sub-Dimensions & Week & \multicolumn{2}{c}{ Increase } & \multicolumn{2}{c}{ No Change } & \multicolumn{2}{c}{ Decrease } \\
\cline { 2 - 7 } & & $f$ & $\%$ & $f$ & $\%$ & $f$ & $\%$ \\
\hline Aesthetics & week 2 $\rightarrow$ week 1 & 42 & 56.7 & 7 & 9.5 & 25 & 33.8 \\
\cline { 2 - 7 } & week 3 $\rightarrow$ week 2 & 27 & 36.5 & 8 & 10.8 & 39 & 52.7 \\
\cline { 2 - 7 } & week 4 $\rightarrow$ week 3 & 35 & 47.3 & 10 & 13.5 & 29 & 39.2 \\
\hline Creativity & week 2 $\rightarrow$ week 1 & 42 & 56.8 & 8 & 10.8 & 24 & 32.4 \\
\cline { 2 - 7 } & week 3 $\rightarrow$ week 2 & 29 & 39.2 & 5 & 6.8 & 40 & 54.1 \\
\cline { 2 - 7 } & week 4 $\rightarrow$ week 3 & 38 & 51.4 & 9 & 12.2 & 27 & 36.5 \\
\hline Expression & week 2 $\rightarrow$ week 1 & 35 & 47.3 & 11 & 14.9 & 28 & 37.8 \\
\cline { 2 - 7 } & week 3 $\rightarrow$ week 2 & 40 & 54.1 & 10 & 13.5 & 24 & 32.4 \\
\cline { 2 - 7 } & week 4 $\rightarrow$ week 3 & 24 & 32.4 & 15 & 20.3 & 35 & 47.3 \\
\hline
\end{tabular}

Initially, the weekly variations in the students' writing skill scores were examined (Table 3 ). As can be observed in Table 3, in the aesthetics sub-dimension, it was revealed that $56.7 \%(n=42)$ of the students scored higher in the second week of the implementation when compared to the first week, while 33.8\% ( $n=25)$ received lower scores. Only 9.5\% $(n=7)$ of the students were found to receive the same score in the first two weeks. In other words, it was revealed that $91.5 \%$ of the students' scores were found to change in the weeks following the first two weeks. The change in the scores students received in the second and third weeks was examined. It was found that there was an increase in the scores of $36.5 \%(n=27)$ of the students, while there was a decrease in the scores of $52.7 \%(n=39)$ of the students; the scores of $10.8 \%(n=8)$ of the students remained the same in these two weeks. In the second and third week of the implementation, the aesthetics scores of $89.2 \%$ of the students were found to have changed. It was observed that $47.3 \%(n=35)$ of the students participating in the study received higher scores in aesthetics in the fourth week when compared to the third week, while $39.2 \%(\mathrm{n}=29)$ received lower scores; $13.5 \%(\mathrm{n}=10)$ of the students' scores remained the same. Thus, $33.8 \%(\mathrm{n}=25)$ of the students' aesthetics scores were found to have changed in the third and fourth weeks.

As can be observed in Table 3, in the creativity sub-dimension, it was revealed that $56.8 \%(n=42)$ of the students participating in the study scored higher in the second week of the implementation, when compared to the first week, while 32.4\% $(\mathrm{n}=24)$ received lower scores. $10.8 \%(\mathrm{n}=8)$ of the students were found to receive the same score in the first and second weeks. In other words, it was revealed that $89.2 \%$ of the students' creativity scores were found to be different in the first and second week. It was found that $39.2 \%(n=29)$ of the students' creativity scores were higher in the third week than they were in the second week, while $54.1 \%(n=40)$ of the students' scores were lower. The creativity scores of $6.8 \%(n=5)$ of the students were found to remain the same in the second and third weeks. Overall, the creativity scores of $93.2 \%$ of the students participating in the study were found to have changed throughout these weeks. The study also revealed that $51.4 \%(\mathrm{n}=38)$ of the students participating in the study received higher creativity scores in the fourth week when compared to the third week, while $36.5 \%(n=27)$ received lower scores. $12.2 \%(n=9)$ of the students were found to receive the same creativity scores in the third and fourth weeks. Overall, it can be observed that $87.8 \%$ of the students' creativity scores changed in the last two weeks.

As can be observed in Table 3, in the expression sub-dimension, it was revealed that $47.3 \%(\mathrm{n}=35)$ of the students scored higher in the second week of the implementation when compared to the first week, while $37.8 \%(n=28)$ received lower scores. On the other hand, $14.9 \%(n=11)$ of the students were found to receive the same scores in the expression sub-dimension in the first two weeks. It was also revealed that $54.1 \%(\mathrm{n}=40)$ of the students participating in the study received higher scores in the expression sub-dimension in the third week, when compared to the second week, while $32.4 \%$ (n $=24)$ received lower scores. On the other hand, $13.5 \%(\mathrm{n}=10)$ of the students were found to have received the same scores in the expression sub-dimension in the second and third weeks. Overall, $86.5 \%$ of the students' expression scores were observed to have changed throughout these weeks. It 
was also found that $32.4 \%(\mathrm{n}=24)$ of the students participating in the study received higher scores in the fourth week than they did in the third week, while $47.3 \%(n=35)$ received lower scores. The results showed that $20.3 \%(n=15)$ of the students' expression scores remained the same in the third and fourth weeks. Overall, there was a change in the scores of $79.7 \%$ of the students participating in the study in the expression sub-dimension. In conclusion, the study revealed that the scores of students in all three sub-dimensions -Aesthetics, Expression, and Creativity- varied (increased or decreased) in the repeated measurements. As a result of the close examinations, it was observed that even though a student may have received the same total score in two measurements, the scores received in any of the sub-dimensions throughout the four weeks were not the same. In other words, there was no student receiving the same score for aesthetics, creativity, and expression throughout the four weeks. Sample responses received from the students in the scope of the present study are presented in Table 4.

Table 4. Example

\begin{tabular}{|c|c|c|}
\hline Changes & Week & Text Completion \\
\hline \multirow{4}{*}{$\begin{array}{l}\text { Those } \\
\text { displaying } \\
\text { a positive } \\
\text { change }\end{array}$} & 1 & How much he loved her ... the incidents could have proceeded in his favor \\
\hline & 2 & What actually passed through his mind... everything was going to be easier for him \\
\hline & 3 & $\begin{array}{l}\text { What would have changed even if he apologized? What was done was done. Everything was going to } \\
\text { remain the same. Perhaps my conscience was going to soothe. But it was going to continue to stay in } \\
\text { my mind like the first day. }\end{array}$ \\
\hline & 4 & $\begin{array}{l}\text { She was smiling at me but the missing dimple was giving it away. The regret I had been feeling all this } \\
\text { time increased more at that moment. I wished I had never been there, never met that woman. Perhaps I } \\
\text { could not roll back the clock, but I was going to do everything I could to bring back the woman's } \\
\text { dimple. }\end{array}$ \\
\hline \multirow{4}{*}{$\begin{array}{l}\text { Those } \\
\text { displaying } \\
\text { a negative } \\
\text { change }\end{array}$} & 1 & $\begin{array}{l}\text { He shouldn't have given in to the things he heard. If only he had understood the real meaning underlying } \\
\text { what the woman said and hadn't left her alone in the dark well, then everything would have been } \\
\text { different. I wish pride hadn't spoken first, and I wish giving up wouldn't be so easy. }\end{array}$ \\
\hline & 2 & $\begin{array}{l}\text { If only he could say "Maybe", then he would have been saved from the gnawing feeling of blindness } \\
\text { and lived with the hope of the bright days blinding his eyes. The issue wasn't one of seeing but, well, } \\
\text { understanding, for instance. That is, if he had said it at work, perhaps he would have been understood. } \\
\text { Maybe then he wouldn't have had to wait for the blindness to wipe out the dimples he yearned for from } \\
\text { his mind and memories. Maybe then there would have been other things for both of them to wait for ... }\end{array}$ \\
\hline & 3 & $\begin{array}{l}\text { Even if he said it, nothing was going to change any longer. So he preferred to remain silent. Now it was } \\
\text { time to keep quiet, to live through the pain and regret. And that's what he did. He kept quiet. }\end{array}$ \\
\hline & 4 & er, the man could have wanted to be reborn to see that dimple. \\
\hline
\end{tabular}

How do students' performance change over the weeks?

The study initially revealed that the expression, aesthetics, and creativity scores of all the students $(100 \% ; \mathrm{n}=74)$ varied throughout the weeks; none of the students' scores remained the same throughout all the weeks. Subsequently, the combined variation in the expression, aesthetics, and creativity scores was examined, which revealed that there were students scoring similar and different scores with respect to the mentioned sub-dimensions of the writing skill (Figure 2-3).

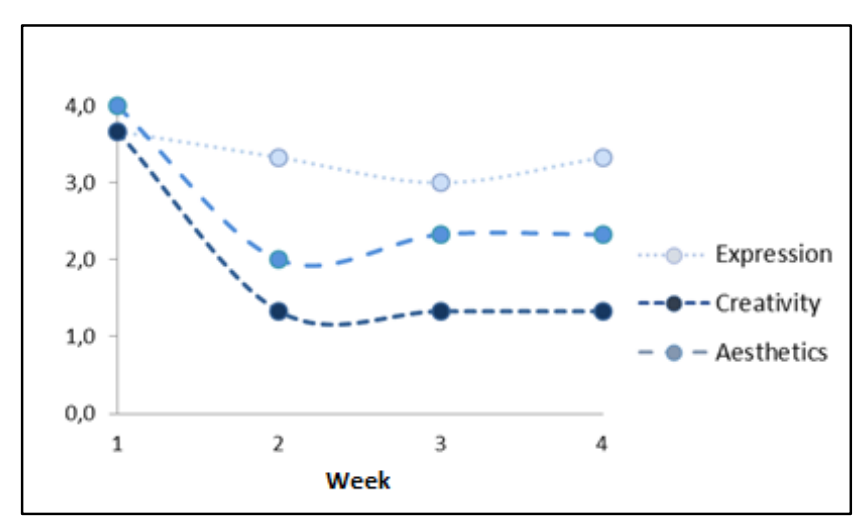

Figure 2. Different - Writing Skills Dissociated in The Context of Sub-Dimensions 


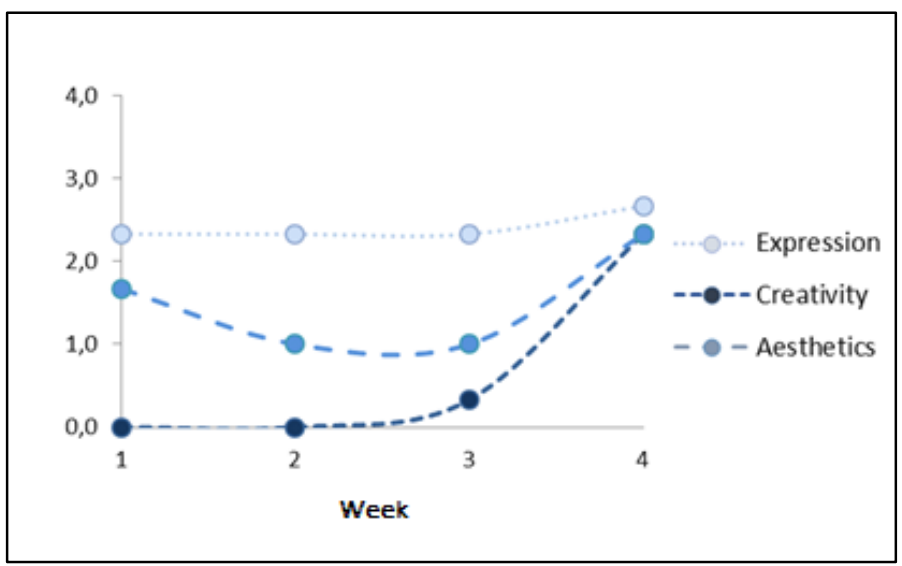

Figure 3. Similar - Writing Skills Dissociated in The Context of Sub-Dimensions

It was revealed that $17.6 \%(\mathrm{n}=13)$ of the students participating in the study had different scores in the sub-dimensions of the writing skill, while $31.1 \%(\mathrm{n}=23)$ had similar scores. It was also revealed that $51.3 \%(\mathrm{n}=38)$ of the students' scores varied weekly and that the variation in the sub-dimension scores showed similarity.

How do students' performance relate to their weekly mood?

Wittgenstein (2004), who stated that "Words assume meaning only within ideas and the flow of life" (p. 114), highlights that perceptions varies from one person to another, that a word or picture can be perceived and conveyed in different ways depending on the context and situation. Thus, the variation in students' writing skills was examined in combination with the change in their weekly mood. The groups that this examination yielded are presented in Figure 4-6.

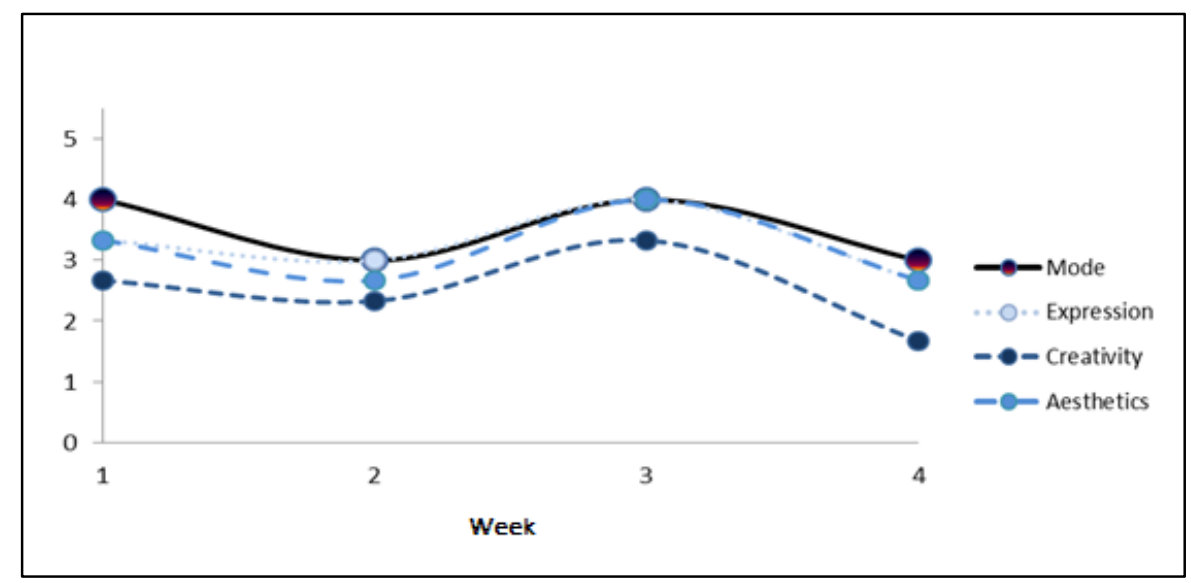

Figure 4. Similar showing an alteration of Weekly Emotional Status with Writing Skill 


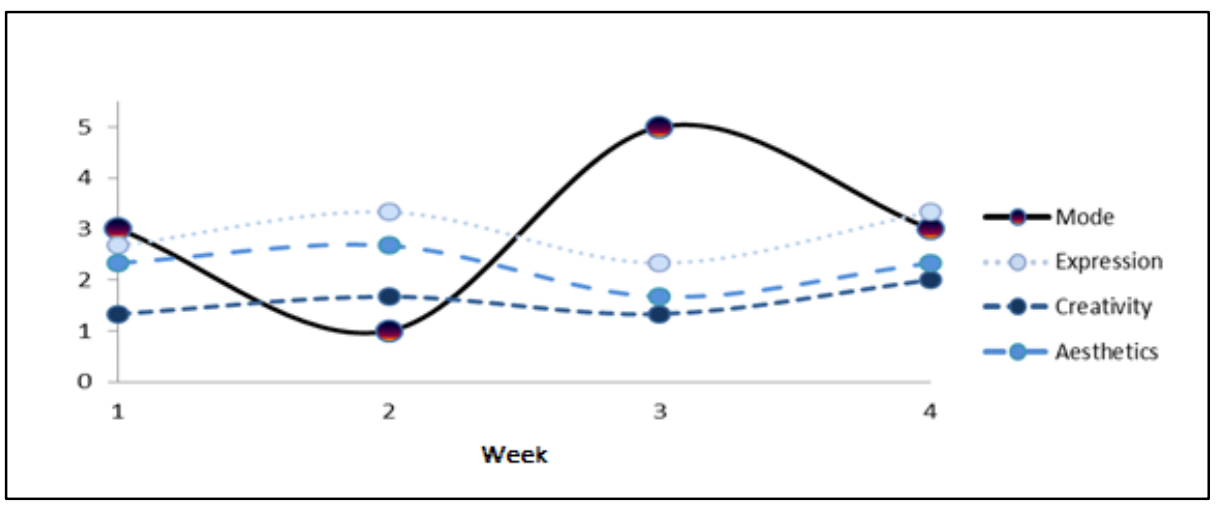

Figure 5. Opposite showing an alteration of Weekly Emotional Status with Writing Skill

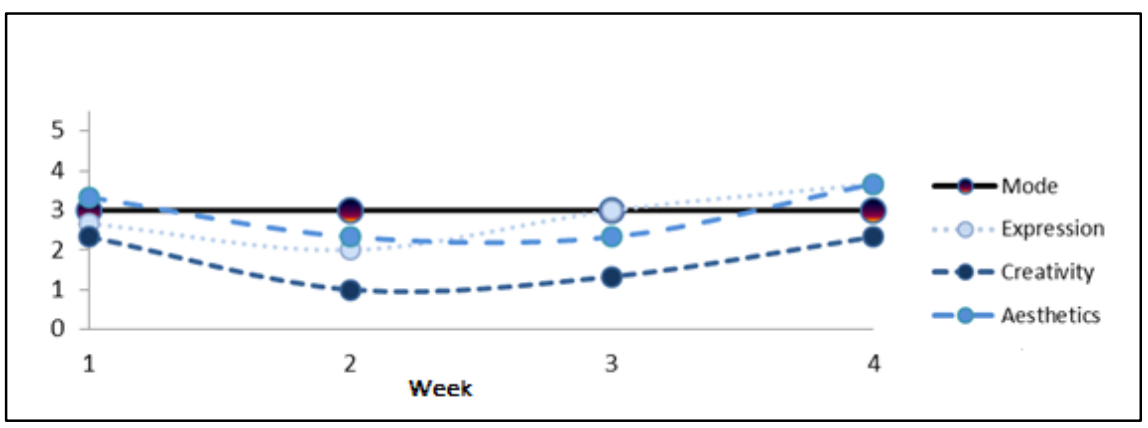

Figure 6. Different showing an alteration of Weekly Emotional Status with Writing Skill

It can be observed that the variation in the aesthetics scores of $36.5 \%(n=27)$ of the students participating in the study show similarity in at least two weeks. The variation in the weekly mood and writing skill sub-dimensions were found to be in the negative (adverse) direction of $28.4 \%(n=21)$ of the students in at least two weeks. The existence of a combined variation in the writing skill and weekly moods of $71.6 \%$ of the students can be considered an indication of the validity and reliability of the student responses in the measurement tool.

How to Interpret Individual Versus Group Level Analysis Results for the Changes Observed in the Writing Subskills (Expression, Aesthetics and Creativity)? How Do Students' Week Moods Affect Their Writing Performance as A Group?

The descriptive statistics of the scores the university students received from the texts based on expression, aesthetics, and creativity throughout the four weeks were calculated; the results are presented in Table 5.

Table 5. Descriptive Statistics

\begin{tabular}{|c|c|c|c|c|c|c|c|}
\hline Dimensions & Week & $\mathrm{N}$ & Minimum & Maximum & $\bar{X}$ & $S_{x}$ & $F$ \\
\hline \multirow{4}{*}{ Aesthetics } & 1 & 74 & 0.00 & 4.00 & 1.93 & 1.03 & \multirow{4}{*}{0.96} \\
\hline & 2 & 74 & 0.00 & 4.00 & 2.14 & 1.07 & \\
\hline & 3 & 74 & 0.67 & 4.00 & 1.99 & 0.85 & \\
\hline & 4 & 74 & 0.00 & 4.00 & 2.05 & 0.98 & \\
\hline \multirow{4}{*}{ Creativity } & 1 & 74 & 0.00 & 3.67 & 1.23 & 0.88 & \multirow{4}{*}{$3.23^{*}$} \\
\hline & 2 & 74 & 0.00 & 4.00 & 1.54 & 1.05 & \\
\hline & 3 & 74 & 0.33 & 3.33 & 1.35 & 0.81 & \\
\hline & 4 & 74 & 0.00 & 3.33 & 1.52 & 0.80 & \\
\hline \multirow{4}{*}{ Expression } & 1 & 74 & 0.67 & 4.00 & 2.42 & 0.85 & \multirow{4}{*}{$4.04 * *$} \\
\hline & 2 & 74 & 0.00 & 3.67 & 2.54 & 0.86 & \\
\hline & 3 & 74 & 1.33 & 4.00 & 2.79 & 0.74 & \\
\hline & 4 & 74 & 0.00 & 4.00 & 2.59 & 0.84 & \\
\hline
\end{tabular}

$* p<.05, * * p<.01$ 
Upon the examination of the information in Table 5, it can be seen that the aesthetics sub-dimension scores of the students varied between 0.00 and 4.00 during the first week of the implementation. The average of the students' aesthetics scores was calculated to be $1.93( \pm 1.03)$. The average aesthetic scores for the second, third and fourth weeks were calculated to be $2.14( \pm 1.07), 1.99( \pm 0.85), 2.05$ $( \pm 0.98)$, respectively. Variance analysis in the repeated measures was calculated to identify whether or not there was a significant variation in the average scores received by the students in different weeks; the analysis yielded no significant variation in the students' average scores across the weeks $(F=0.96 ; p>.05)$.

It is observed that the scores the students received in the creativity sub-dimension varied between 0.00 and 3.67 in the first week of the implementation. The average creativity score of week 1 was calculated to be $1.23( \pm 0.88)$. The average creativity scores of the students for the second, third, and fourth weeks were calculated to be $1.54( \pm 1.05), 1.35( \pm 0.81), 1.52( \pm 0.80)$, respectively. The repeated measurements revealed that there was a significant variation in the students' average scores in the creativity sub-dimension across the weeks $(\mathrm{F}=3.23 ; p<.05)$. Multiple comparison Bonferroni test was calculated in order to determine between which measurements the difference is. I. and II. Considering the errors made in multiple comparisons due to type error risks, Bonferroni test (Kayri, 2009 ) with the least bias was used. In order to reveal the variation, a multiple comparative Bonferroni test was utilized. As a result of this test, it was found that the scores obtained by the students in the fourth week were significantly higher than the scores they received in the first week.

With respect to the expression sub-dimension, it was revealed that the scores obtained by the students in the first week ranged between 0.67 and 4.00; their average was calculated to be $2.42( \pm 0.85)$. The students' average scores in the sub-dimension of expression for the second, third, and fourth weeks were calculated to be $2.54( \pm 0.86), 2.79( \pm 0.74), 2.59( \pm 0.84)$, respectively. As a result of the variance analysis run for the repeated measurements, there was a significant variation in the students' average scores in the sub-dimension of expression $(F=4.041 ; p<.05)$. The Bonferroni test results indicated that the average score of the students' scores in the expression dimension during the third week was significantly higher than the average score for the first week.

Upon the examination of the variation between a single group of 74 people groups, it can be observed that there was no change in the sub-dimensions of the students' writing skill or the effect of the variation was very small. In other words, it was revealed that the variations observed in students individually disappeared in the group analyses.

\section{What Is the Relationship Between Writing Skills and Weekly Modes In The Context Of Expression Versus Aesthetics Versus Creativity? Do the Findings Support the Theoretical Developments in This Field?}

In order to determine the effect of students' writing skills on weekly emotional states in repeated measurements, discrimination analysis was performed. Within the scope of the present study, initially, the frequencies and percentage values of students' weekly moods were calculated. In the first week of the implementation, the students indicated that of $2.7 \%(\mathrm{n}=2)$ of them had spent the week highly negatively, $17.6 \%(\mathrm{n}=13)$ negatively, $51.4 \%(\mathrm{n}=38)$ neither positively nor negatively, $25.7 \%(\mathrm{n}=$ 19) positively, and $2.7 \%(\mathrm{n}=2)$ highly positively. In the second week, it was reported that $8.1 \%(\mathrm{n}=$ $6)$ of the students had spent the week highly negatively, 28.4\% $(\mathrm{n}=21)$ negatively, $40.5 \%(\mathrm{n}=30)$ neither positively nor negatively, $20.3 \%(\mathrm{n}=15)$ positively, and $2.7 \%(\mathrm{n}=2)$ highly positively. In the third week, it was reported that $6.8 \%(\mathrm{n}=5)$ of the students had spent the week highly negatively, $5.4 \%(\mathrm{n}=4)$ negatively, $33.8 \%(\mathrm{n}=25)$ neither positively nor negatively, $41.9 \%(\mathrm{n}=31)$ positively, and $12.2 \%(n=9)$ highly positively. In the last week of the implementation, the students' responses indicated that $6.8 \%(\mathrm{n}=5)$ of the students had spent the week negatively, 33.8\% $(\mathrm{n}=25)$ neither positively nor negatively, $55.4 \%(n=41)$ positively, and $4.1 \%(n=3)$ highly positively. 
Because there was limited data, the students were categorized into two groups of negative + netural and positive weekly moods by taking into consideration the weekly reported mood scores and the average mood scores of the four weeks.

The validity of the weekly mood categorization based on students' sub-dimension scores of the writing skill was examined. The analysis was done by making calculations initially for each week and then for the four-week average scores. An average score in the context of aesthetics, expression, and creativity was obtained by first taking the average of six dimensions of students' four-week writing skills. Then, by taking the average of the emotional states they stated for each week, an average emotional score was calculated for the students. Due to the low number of data, students' emotions were classified into two groups as negative + neutral and positive. The descriptive statistics of students' writing skill scores based on weekly moods are presented in Table 6 .

Table 6. Descriptive Statistics Based on Weekly Mood

\begin{tabular}{llrr}
\hline Weekly Mood & Dimensions & $\bar{X}$ & $S_{x}$ \\
\hline \multirow{3}{*}{ Negative or Neutral } & Aesthetics & 1.77 & 0.62 \\
\cline { 2 - 4 } & Creativity & 1.18 & 0.55 \\
\cline { 2 - 4 } & Expression & 2.42 & 0.55 \\
\hline \multirow{3}{*}{ Positive } & Aesthetics & 2.48 & 0.68 \\
\cline { 2 - 4 } & Creativity & 1.80 & 0.66 \\
\cline { 2 - 4 } & Expression & 2.88 & 0.54 \\
\hline \multirow{2}{*}{ Total } & Aesthetics & 1.03 & 0.73 \\
\cline { 2 - 4 } & Creativity & 2.59 & 0.66 \\
\cline { 2 - 4 } & Expression & 0.59 \\
\hline
\end{tabular}

As seen in Table 6, the aesthetics, creativity, and expression skills scores of students with a good fourweek average emotional state. It is observed that the mood is higher than the students with mediumlow level. The Wilks' Lambda values were calculated to identify to what extent measurements based on aesthetics, creativity, and expression could distinguish students whose moods were positive and those whose moods were moderate/low; the results are presented in Table 7.

Table 7. The Wilks' Lambda Values

\begin{tabular}{lrr}
\hline Sub-Dimensions & Wilks' Lambda & $F$ \\
\hline Aesthetics & .78 & $20.90^{* * *}$ \\
\hline Creativity & .79 & $18.65^{* * *}$ \\
\hline Expression & .85 & $12.37^{* * *}$ \\
\hline$* * * p<.001$ & &
\end{tabular}

When Table 7 is examined, it is seen that aesthetics, creativity, and expression skills make a significant contribution to explaining students' emotional states. Since the weekly mood variable was included in two categories in the research, a single function that clarifies $100 \%$ of the variance for the analysis of separation was calculated. The results are shown in Table 8.

Table 8. The Calculated Values Based on The Discriminant Function

\begin{tabular}{crrrrrrr}
\hline Function & Eigenvalue & $\%$ Variance & $\begin{array}{r}\text { \% Total } \\
\text { variance }\end{array}$ & $\begin{array}{r}\text { Canonical } \\
\text { Correlation }\end{array}$ & $\begin{array}{r}\text { Wilks' } \\
\text { Lambda }\end{array}$ & $\begin{array}{r}\text { Chi- } \\
\text { Square }\end{array}$ & \begin{tabular}{l} 
df \\
\hline Average
\end{tabular} \\
\hline$* * * p<.001$ & .31 & 100.0 & 100.0 & .49 & .76 & $19.03 * * *$ & 3 \\
\hline
\end{tabular}

As seen in Table 8, it is seen that the function created to separate the emotional states of the students is significant $(p<.05)$. And the sub-dimensions of writing skills classify the emotional state at a 
Sayın, A., Kahraman, N. / A Measurement Tool for Repeated Measurement of Assessment of University Students' Writing Skill: Development and Evaluation

medium level $(\mathrm{r}=.49)$. The canonical correlation coefficients and the structure matrix correlation coefficients, calculated in relation to score types accounting for the categorization of students' fourweek general average moods, are presented in Table 9.

Table 9. Standardized Canonical Correlation Coefficients and Structure Matrix Correlation Coefficients of Sub-scores

\begin{tabular}{lrr}
\hline Function & Canonical & Structure Matrix \\
\hline Aesthetics & .94 & .97 \\
\hline Creativity & .42 & .91 \\
\hline Expression & .40 & .74 \\
\hline
\end{tabular}

When the information in Table 9 is examined, it can be observed that it is the aesthetics score that accounts for the categorization of students' four-week general moods most, while it is the aesthetics score that accounts for it the least. The expected and observed values and percentages of individuals in the categorization of students' general weekly moods are presented in Table 10.

Table 10. Decisions of intersecting Categorizations Based on The Discriminant Analysis

\begin{tabular}{llrrr}
\hline Original number of individuals & Weekly Mood & \multicolumn{2}{c}{ Intersecting number of students } & \multirow{2}{*}{ Total } \\
\cline { 3 - 5 } & & Negative/Neutral & Positive & 33 \\
\hline \multirow{2}{*}{ Number of students } & Negative/Neutral & 8 & 14 & 47 \\
\cline { 2 - 5 } & Positive & 70.2 & 19 & 27 \\
\hline$\%$ & Negative/Neutral & 29.6 & 70.4 & 100.0 \\
\cline { 2 - 5 } & Positive & 100.0 \\
\hline
\end{tabular}

As can be seen in Table 10, the writing sub-dimension scores have accurately categorized $70.2 \%(\mathrm{n}=$ 33 ) of the students whose weekly moods were negative/neutral and $70.4 \%(\mathrm{n}=19)$ of the students whose weekly moods were positive. It was found that a total of $70.3 \%$ of the students were categorized accurately.

\section{DISCUSSION and CONCLUSION}

The primary aim of the present study was to develop an alternative measurement tool to enable the observation of students' higher-order writing skills via repeated measures and the identification of more stable or dynamic sub-dimensions and the examination of the relationships among them. Within this scope, the story completion technique was utilized to measure students' writing skills in terms of their sub-dimensions: aesthetics, expression, and creativity. Different from the story completion technique, a story was written in line with the post-modern movement, and then it was divided into four sections, ensuring that each section was unified in itself. Each section was given to the students each week so that they could complete the text by writing several sentences. Since the skill of writing tends to change by nature (Borgonovi \& Pál, 2016), it must be repeatedly measured to measure the skill. Accordingly, there is a need for new measurement tools that will allow students' performances to be monitored as a growth process.

Kahraman, Akbaş and Sözer (2019) mention that longitudinal measurement models can be used for modeling systematic and controlled assessment spreads over time. İlker and Melekoğlu (2017) emphasize that longitudinal studies are needed in the study of writing skills, especially in special education. Akyüz and Doğan (2017) also mention the importance of conducting longitudinal studies in the process of an in-depth study of literacy skills. Similarly, Funder (2006) points out that the measurements of the behaviors acquired in a process should not be in one go. Since longitudinal studies allow the monitoring of the effects of the time factor (Werner, 2013; Norris, Tracy, \& Galea, 2009), the measurement of the behavior gained over time also needs to be measured based on time. 
Accordingly, there is a need for measurement tools that will allow students to track their writing skills over time, not at once.

In the current study, an alternative measurement tool was studied to be used to provide feedback to students with respect to their sub-writing skills. Namely, a longitudinal measurement tool was developed containing repeated assessments. The results from the conducted application study revealed that there were, in fact, variations in the writing skills of students in terms of aesthetics, expression, and creativity subskills, and this was so for most of the students over the four weeks. The changes were not always suggestive of growth. This suggests that other factors than students writing ability were playing a role in their performances. Such factors may include but are not limited to students' familiarity with the storyline, adaptation level to the task process, curiosity, motivation or well-being at the time of writing. Our results suggest that it might be that as students continued to write to the same storyline over the weeks, 1) some may have become more aware of their own potential versus productivity in writing and performed better and 2) some have lost their motivation and experienced a decline in their writing performance. Regardless of the outcome in scoring, these findings suggest that the assessment format being "longitudinal" rather than cross-sectional, it was possible to infer from the ratings that some factors other than those related to the cognitive processes alone play a role when it comes to portray advanced writing skills.

These findings exemplify the probable contributions of examining within-person variations through repeated measures while investigating between-person variations. With repeated and meaningful observations, it is particularly important to develop measurement tools in which individuals' general well-being, interest, desire, and motivation levels are taken into consideration, especially when higherorder skills are of interest. Avey, Luthans and Mhatre (2008) point out that determining the feature that is the subject of measurement based on longitudinal measurement approach shows changes and developments over time, and the observed effect sizes are important in terms of enabling emotionalization. The results obtained in this study illustrate that the weekly changes in students' moods can have a profound effect on their writing performance, not on the sub-dimension of expression but on the sub-dimension of creativity, more so for some students than others.

Even though there was a significant variation in the individual writing scores of the students participating in the study throughout the four-week period, it was observed that the between-group differences became weaker or disappeared totally over the weeks. This shows that non-linear variations can be overlooked within a group, and thus, group-based examinations can be insufficient in revealing individual-based (within-person) variations. A literature review indicates that in studies focusing on measuring the writing skill (Çıral1, 2014), analyses were often carried out with average scores over groups. Kahraman et al. (2019) report that traditional one-shot assessment tools may not be sensitive enough to capture within-person variations when cognitive or affective skills of interest are prone to change or subject to growth over time. Muthén \& Curran (1997) points out that longitudinal measurement emotional states provide reliable and valid evidence for measuring and evaluating individual differences. In the application carried out within the scope of this research, it was determined that the individual changes of the students disappeared in group-based examinations.

Given the results of the present study, researchers are recommended to investigate if the construct they are interested in measuring is subject to change over time, and if so, to consider formulating a repeated assessment design, one that preferably includes relevant affective measures, such as, motivation. This way, additional valuable data may be collected to support the validity of the inferences to be made using the assessment results.

In the present study, 74 students were reached. A similar study can be conducted with more students to examine the relationship between the writing skill and its sub-dimensions and their factor load values by means of multiple group models. Within the scope of the study, an appropriate text to fit the event story was constructed. Making similar measurement tools more common via different techniques is recommended.

As it was observed in the results of the present study, individual differences might be overlooked if data analyses are based on group differences alone; so that, it is recommended that within person 
differences should also be investigated, especially when there is potential for growth in students' side, that is, to track growth or support change in individuals' performance over time. This would help researchers understand the factors that may help or hinder student performance better.

During the present research, the Aesthetics, Expression, and Creativity sub-dimensions were coded in the scoring rubric. In other studies, the tone of texts, such as a sad tone, a happy ending etc. in the stories that the students complete can be examined with respect to features such as empathy and the language style of the narrator.

\section{Acknowledgment}

We thank research assistant Sebahat Gören Kaya, Derya Akbaş, Ergün Cihat Çorbacı and Esra Sözer who helped us during the data collection and scoring stages of this research.

\section{REFERENCES}

Akyüz, E., \& Doğan, Ö. (2017). Ev okuryazarlık ortamı: Tanımları, boyutları ve kendiliğinden ortaya çıkan okuryazarlık becerilerinin gelişimindeki rolü. H.Ü. Sağllk Bilimleri Fakültesi Dergisi, 4(3), 38-57. Retrieved from http://static.dergipark.org.tr/article-download/f05d/90fc/2b9b/5a44d125671b5.pdf?

Avey, J. B., Luthans, F., \& Mhatre, K. H. (2008). A call for longitudinal research in positive organizational behavior. Journal of Organizational Behavior: The International Journal of Industrial, Occupational and Organizational Psychology and Behavior, 29(5), 705-711. doi: 10.1002/job.517

Borgonovi, F., \& Pál, J. (2016). A framework for the analysis of student well-being in the PISA 2015 study. Paris: OECD Publishing.

Brown, H. D. (2001). Teaching by principles: An interactive approach to language pedagogy. New York, NY: Addison Wesley Longman.

Butler, D. L., \& Schnellert, L. (2012). Collaborative inquiry in teacher professional development. Teaching and Teacher Education, 28(8), 1206-1220. doi: 10.1016/j.tate.2012.07.009

Büyüköztürk, Ş., Çakmak, E. K., Akgün, Ö. E., Karadeniz, Ş., \& Demirel, F. (2010). Bilimsel araştırma yöntemleri. Ankara: PegemA Akademi.

Carini, P. F. (2001). Starting strong: A different look at children, schools, and standards. New York, NY: Teachers College Press.

Çıralı, H. (2014). Dijital hikâye anlatımının görsel bellek ve yazma becerisi üzerine etkisi (Yayımlanmamış yüksek lisans tezi, Hacettepe Üniversitesi, Ankara). Erişim adresi: http://tez2.yok.gov.tr/

Cohen, L., Manion, L., \& Morrison, K. (2005). Research methods in education. (5th ed.). London: Routledge Falmer.

Comber, B., \& Barnett, J. (Eds.). (2003). Look again: Longitudinal studies of children's literacy learning. Newtown, Australia: Primary English Teaching Association.

Compton-Lilly, C. (2003). Reading families: The literate lives of urban children. New York, NY: Teachers College Press.

Coşkun, E. (2013). Yazma becerisi. A. Kırkkılıç ve H. Akyol (Ed.), Illköğretimde Türkçe öğretimi içinde (ss. 4991). Ankara: Pegem Akademi.

Ekwall, E. E., \& Shanker, J. L. (1993). Ekwall/Shanker reading inventory. Boston, MA: Allyn \& Bacon.

European Commission. (2006). Report promoting cultural education in Europe: A contribution to participation, innovation and quality. Austrian Presidency.

Fraenkel, J. R., \& Wallen, N. E. (2009). How to design and evaluate research in education. (7th ed.). New York, NY: McGraw-Hill International Edition.

Funder, D. C. (2006). Towards a resolution of the personality triad: Persons, situations, and behaviors. Journal of Research in Personality, 40(1), 21-34. doi: 10.1016/j.jrp.2005.08.003

Horng, J. S., Hong, J. C., \& Chanlin, L. J. (2005). Creative teachers and creative teaching strategies. International Journal of Consumer Studies, 29(4), 352-358. doi: 10.1111/j.1470-6431.2005.00445.x

İlker, Ö., \& Melekoğlu, M. A. (2017). İlköğretim döneminde özel öğrenme güçlüğü olan öğrencilerin yazma becerilerine ilişkin çalışmaların incelenmesi. Ankara Üniversitesi Ĕ̆itim Bilimleri Fakültesi Özel Ĕ̆itim Dergisi, 18(3), 443-469. doi: 10.21565/ozelegitimdergisi.318602

Kahraman, N., Akbaş, D., \& Sözer, E. (2019). Bilişsel olmayan öğrenme durum ve süreçlerini ölçme ve değerlendirmede boylamsal yaklaşimlar: Duygu cetveli uygulamasi örneği. Abant İzzet Baysal Üniversitesi Eğitim Fakültesi Dergisi, 19(1), 257-269. doi: 10.17240/aibuefd.2019.19.43815-459831 
Karadüz, A. (2010). Dil becerileri ve eleştirel düşünme. Turkish Studies 5(3), 1566-1593. doi: 10.7827/TurkishStudies. 1572

Karasar, N. (2008). Bilimsel araştırma yöntemleri. İstanbul: Nobel Yayın Dağıtım.

Kayri, M. (2009). Araştırmalarda gruplar arası farkın belirlenmesine yönelik çoklu karşılaştırma (post-hoc) teknikleri. Fırat Üniversitesi Sosyal Bilimler Dergisi, 19(1), 51-64, http://web.firat.edu.tr/sosyalbil/dergi/arsiv/cilt19/sayi1/051-064.pdf adresinden edinilmiştir.

Kolcu, A. İ. (2013). Öykü sanatı. Erzurum: Salkımsöğüt Yayınları.

Lemke, J. (2005). Place, pace, and meaning: Multimedia chronotopes. In S. Norris \& R. H. Jones (Eds.), Discourse in action: Introducing mediated discourse analysis (pp. 110-122). New York, NY: Routledge

Leslie, L., \& Caldwell, J. (2006). Qualitative reading inventory. Reading, MA: Allyn \& Bacon.

Muthén, B. O., \& Curran, P. J. (1997). General longitudinal modeling of individual differences in experimental designs: A latent variable framework for analysis and power estimation. Psychological Methods, 2(4), 371-402. Retrieved from https://www.jhsph.edu/research/centers-and-institutes/johns-hopkins-centerfor-prevention-and-early-intervention/Publications/muthen.curran.1997.pdf

Mesleki Yeterlik Kurumundan; Türkiye Yeterlilikler Çerçevesine Dair Tebliğ. (Tebliğ No: 2015/1). Türkiye Yeterlilikler Çerçevesi. Resmî Gazete, 29581, 02.01.2016

Norris, F. H., Tracy, M., \& Galea, S. (2009). Looking for resilience: Understanding the longitudinal trajectories of responses to stress. Social Science \& Medicine, 68(12), 2190-2198. doi: 10.1016/j.socscimed.2009.03.043

Oral, G. (2014). Yine yazı yazıyoruz. Ankara: Pegem Akademi Yayıncılık.

Richardson, G. M., \& Liang, L. L. (2008). The use of inquiry in the development of preservice teacher efficacy in mathematics and science. Journal of Elementary Science Education, 20(1), 1-16. doi: 10.1007/BF03174699

Ülper, H. (2008). Bilişsel süreç modeline göre hazırlanan yazma öğretimi programının öğrenci başarısına etkisi (Doktora tezi, Ankara Üniversitesi Sosyal Bilimler Enstitüsü, Ankara). Erişim adresi: http://tez2.yok.gov.tr/

Werner, E. E. (2013). What can we learn about resilience from large-scale longitudinal studies? In S. Goldstein \& R. B. Brooks (Eds.), Handbook of resilience in children (pp. 91-105). Boston, MA: Springer US

Wittgenstein L. (2004). Tractatus logico-philosophicus. London: Routledge \& Kegan Paul.

Wittgenstein, L. (2005). Philosophical grammar. USA: University of California Press.

Wittgenstein, L. (2012). Philosophical investigations. UK: Blackwell Publishing.

Wittgenstein, L. (2014). Recherches philosophiques. Paris: Editions Gallimard.

Yakıc1, A., Yücel, M., Doğan, M., \& Yelok, S. (2016). Yazılı anlatım üniversiteler için Türkçe-1. Ankara: Yarg1 Yayınevi. 